\title{
Different slopes of a mountain can determine the structure of ferns and lycophytes communities in a tropical forest of Brazil
}

\author{
FELIPE C. NETTESHEIM ${ }^{1}$, ELAINE R. DAMASCENO ${ }^{2}$ and LANA S. SYLVESTRE ${ }^{3}$ \\ ${ }^{1}$ Universidade Federal do Rio de Janeiro, Programa de Pós-graduação em Ecologia, CCS, \\ Ilha do Fundão, 21941-590 Rio de Janeiro, RJ, Brasil \\ ${ }^{2}$ Universidade Federal do Rio de Janeiro, Programa de Pós-graduação em Botânica, Museu Nacional, \\ Quinta da Boa Vista, s/n, São Cristóvao 20940-040 Rio de Janeiro, RJ, Brasil \\ ${ }^{3}$ Universidade Federal do Rio de Janeiro. Departamento de Botânica, CCS, Instituto de Biologia, \\ Ilha do Fundão, 21941-902 Rio de Janeiro, RJ, Brasil
}

Manuscript received on Febryary 16, 2012; accepted for publication on March 28, 2013

\begin{abstract}
A community of Ferns and Lycophytes was investigated by comparing the occurrence of species on different slopes of a paleoisland in Southeastern Brazil. Our goal was to evaluate the hypothesis that slopes with different geographic orientations determine a differentiation of Atlantic Forest ferns and lycophytes community. We recorded these plants at slopes turned towards the continent and at slopes turned towards the open sea. Analysis consisted of a preliminary assessment on fern beta diversity, a Non Metric Multidimensional Scaling (NMDS) and a Student t-test to confirm if sites sampling units ordination was different at each axis. We further used the Pearson coefficient to relate fern species to the differentiation pattern and again Student's $\mathrm{t}$-test to determine if richness, plant cover and abundance varied between the two sites. There was a relatively low number of shared species between the two sites and ferns and lycophytes community variation was confirmed. Some species were detected as indicators of the community variation but we were unable to detect richness, plant cover or abundance differences. Despite the evidence of this variation between the slopes, further works are needed to evaluate which processes are contributing to determine this pattern.
\end{abstract}

Key words: Atlantic rain forest, topography, pteridophytes, richness, environmental factors.

\section{INTRODUCTION}

Plant species distribution within tropical forest landscapes has been shown to be generally determined by factors which vary from biogeographic to microenvironmental scales (Svenning 1999, Ter Steege et al. 2003, Condit et al. 2002). Ranging from local to regional scales, several studies have shown that plant species composition and abundances answer to some common environmental variables

Correspondence to: Lana da Silva Sylvestre

E-mail: lana@biologia.ufrj.br such as topography (Vormisto et al. 2004), soil characteristics (Jones et al. 2006, Tuomisto et al. $2003 \mathrm{~b}, \mathrm{c}$ ), length of the dry period and moisture availability (Engelbrecht et al. 2005). Although there is considerable debate as to what degree floristic distributional patterns depend on environmental factors relative to other processes (Hubbell 2001, Dalling et al. 2002, Wyatt and Silman 2004), findings appear to show that the major role is played by environmental factors (Karst et al. 2005, Jones et al. 2006, 2008, Zuquim et al. 2009). 
The environmental model has provided consistently better predictive power for Amazonian ferns structure than for trees and palms (Ruokolainen et al. 1997, Pitman et al. 2001, Potts et al. 2002, Tuomisto et al. 2003a, b, c, Phillips et al. 2003, Vormisto et al. 2004). It is reasonable to associate such a result to the fact that ferns are plants which present variable taxon specific establishment success. These plants have adaptations to low levels of light incidence, low evaporative potentials, a unique water dependent reproductive biology and high sensibility to abiotic features such as substrate. Therefore ferns and lycophytes communities structure are expected to be very subjective to environmental changes related to solar irradiance and atmosphere moisture levels (Wylie 1948, Barrington 1993, Chazdon et al. 1996, Sonoike 1996, Page 2002). Only recently, studies started addressing such issues in the Atlantic forest with plant groups. Therefore, knowledge about the relative contribution of environmental factors to explain floristic composition variation along the Atlantic forest is still starting to stack up (OliveiraFilho and Fontes 2000, Oliveira-Filho et al. 2005, Paciencia and Prado 2005, Duarte et al. 2010, Machado and Oliveira-Filho 2010, Nettesheim et al. 2010, Marques et al. 2011, Garbin et al. 2012). The extensive habitat heterogeneity along a wide range distribuition (Tonhasca Jr 2005) makes this forest a good model to test recent findings regarding tropical plants distributional patterns (Svenning et al. 2010, Jones et al. 2011, Kluge and Kessler 2011, Ricklefs and Renner 2012).

A particular group containing good potential for the study of the processes regulating plants distribution in the Atlantic forest appears to be the ferns. Not only do they have high richness and endemism levels (Tryon and Tryon 1982), but they are known to have had a large part of its floristic variation consistently predicted by environmental variation. Among the array of environmental factors, topographic and edaphic factors appear to be noticeably important at different scales (Karst et al. 2005, Jones et al. 2006, 2008, Zuquim et al. 2009). It is thus reasonable to think that ferns exposed to the geomorphologic heterogeneity along the Atlantic Forest would be influenced by environmental variation. This might be especially true where topography is highly variable and close to the ocean, being subjected to very humid cold fronts and sea wind (Barbosa 2007). Such a geographical situation is likely to cause changes in factors that are relevant for fern occurrence, such as moisture and light incidence. Literature has registered that ferns leaf length appears to decrease with increasing aridity while locations with greater moisture normally have greater diversity and abundance (Page 2002, Kessler et al. 2007). Throughout the year, southeastern Brazilian forests located in northerly slopes have greater exposure to sunlight than those located in southerly slopes (Lima 1986, Oliveira et al. 1992, Marques et al. 2005). Studies in this region show that areas turned to the ocean are indeed more humid due to a greater mean annual rainfall than areas turned inland (Oliveira-Filho and Fontes 2000, Oliveira et al. 2005, Paciencia and Prado 2005, Nettesheim et al. 2010). These efforts argue that such patterns are in general agreement with the Atlantic forest's evergreen and seasonal distribution, apparently limited by annual rain and principally by the duration of the dry period.

Once many efforts have consistently predicted ferns and lycophytes floristic variation using environmental models and assuming different slopes near the ocean are likely to exhibit environmental variation, the aims of this study were: (1) determine if, as expected, there is floristic variation of the Atlantic forest ferns community between two different slopes of a paleoisland (northern-facing vs. southwestern-facing); (2) considering that the southwestern slopes are more humid than the northwestern slopes, determine if it has greater fern richness, abundance and plant cover area. 


\section{MATERIALS AND METHODS}

\section{STUDY SiTE}

Marambaia paleoisland is a portion of granitegneiss crystalline basement land linked to the continent by Marambaia Restinga. It is located south of the State of Rio de Janeiro (2304'37.09"S; 4359'2.15"W), in Sepetiba Bay, on Mangaratiba municipality. The paleoisland together with Serra do Mar Range is a consequence of tectonic activity which dates back to the Jurassic Period (130 million years ago), associated with rupture of ancient Gondwana supercontinent (Almeida and Carneiro 1998). Marambaia paleoisland was formerly isolated from the Serra do Mar Range by rising ocean level in the quaternary (Menezes et al. 2005, Souza et al. 2005). It is covered with 2,125.43ha of Atlantic rain forest, characterized by Veloso et al. (1991) as a Sub-Montane Dense Ombrophylous Forest. The terrain altitude varies from 0 to 641 meters. The site is encompassed as macroclimate Aw (Rainy Tropical Climate - Köppen 1948). Climatic data from a meteorological station located $35 \mathrm{~km}$ from study area at Marambaia Restinga indicates average monthly temperatures from 1986 to 1998 ranging between $20.9^{\circ} \mathrm{C}$ and $26.9^{\circ} \mathrm{C}$. Mean annual precipitation is $1,239.7 \mathrm{~mm}$ (Mattos 2005).

SAMPLING

Field activities were conducted between January of 2007 and January of 2008. We evaluated two sampling sites at Marambaia paleoisland. The sampling sites were two contiguous areas. One site was comprised of slopes facing the continent on a main northwestern geographic orientation (site A) and the other were slopes turned to the open sea on a main southwestern geographic orientation (site B). Given the total area withheld by the contiguous sampling sites, our study addresses the issue at the mesoscale. It covered a portion greater than 1 ha and smaller than tens of square kilometers (Duivenvoorden et al. 2002, Karst et al. 2005).
A total of thirty $5 \times 5 \mathrm{~m}$ individual sample units (plots) were arbitrarily established at each of the two studied sites. Location of the plots was about $4 \mathrm{~km}$ apart. Plots were scattered to maximize the sampling design reach throughout an altitudinal range between 150 and $300 \mathrm{~m}$ within each site. We established a total of 60 plots (each with $25 \mathrm{~m}^{2}$ ) at Marambaia paleoisland, sampling a total area of $1,500 \mathrm{~m}^{2}$. Plot area was measured close to the ground, since inventory considered terrestrial herbs, tree ferns, plants growing on fallen trees (including in cases where epiphytic species survived the fall), climbers and low trunk epiphytes. We used a tape measure to record width and length of each individual. These values were then multiplied by each other to determine plant cover estimated value. Plantlets were not sampled since the identification of these individuals are inaccurate. Climbing individuals were considered only when at least one green frond was present at maximum $2 \mathrm{~m}$ above the ground (Tuomisto et al. 2002). Once some fern species have the ability to reproduce vegetatively, all individuals considered visually distinct were counted. Yet, some counted individuals may have been ramets of a single clone. We used plant cover as the quantitative variable to avoid eventual bias caused by clonal growth.

Representative voucher specimens of each species were collected for later confirmation of species identification. Unicates and duplicates of the specimens were deposited in the Herbarium of the Department of Botany, Universidade Federal Rural do Rio de Janeiro (RBR), as part of the Marambaia paleoisland fern collection. We followed the classification system of Smith et al. (2006). Authorities for all species were based on Pichi Sermolli (1996) and can be found in the composition table presented in this article. Each species was classified based on field and laboratory observations made during this study as predominantly being either terrestrial, epilithic, hemiepiphytic, facultative epiphyte or climbing. The hemiepiphytic category 
included plants that grow on the ground, but climb trees and branches, losing their connection with the ground to live an epiphytic life, different from the climbing plants that still maintain the connection to the soil through their roots. Facultative epiphyte included plants growing on the trunks and other substrates, as rocks or soil. The epilithic plants were those growing on stones.

\section{DATA ANALYSIS}

As a preliminary assessment on fern beta diversity between the two sites we respectively applied Sørensen and Bray-Curtis distance measures to qualitative (presence/absence) and quantitative (plant cover) species data (McCune and Grace 2002, Magurran 2004). Even though these similarity measures can be good beta diversity estimators to compare both sites, they do not take into account data in each plot.

To overcome this limitation we adopted a multivariate procedure, taking into account species total plant cover in each plot with a data matrix. This way we were able to summarize all the data and reveal its structure helping in the detection of differentiation patterns between the sites (Gauch 1982). Thus, species identity, cover and occurrence were considered simultaneously in a single quantitative species matrix (total plant cover vs. plots). Seeing that Bray-Curtis distance measure could be biased by quantitative data outliers we transformed the data matrix through the Hellinger distance (Legendre and Gallagher 2001). This way we eliminated outliers but magnitude of differences between observations was kept, providing a reliable Bray-Curtis similarity matrix.

We then evaluated this similarity matrix with a Non-Metric Multidimensional Scaling (NMDS). We drew Gauss bivariate ellipses over sites A and B's final NMDS ordination graph. Each ellipse was centered on the sample means of the $\mathrm{x}$ and $\mathrm{y}$ variables. The unbiased sample standard deviations of $\mathrm{x}$ and $\mathrm{y}$ determines its major axes and the sample covariance between $\mathrm{x}$ and $\mathrm{y}$, its orientation. We specified the size of the ellipse with a probability value of 0.65 . A Student's t-test was then applied to evaluate if eventual differences between sites $\mathrm{A}$ and $\mathrm{B}$ plot ordinations on the first two axes were significant. To investigate if any fern species could be pointed out as being community differentiation indicators, we further used the Pearson coefficient to associate species cover in each plot with the NMDS ordination axis. The result of this procedure is shown on a graph as species vectors and point out probable association between species and the sites.

Subsequently we compared sites A and B to test if richness, abundance and total plant cover would be higher in site $\mathrm{B}$. These three dependent response variables were evaluated between the sites by means of a Student's T Test. Normality and homoscedasticity were evaluated through analysis of residuals. When necessary we transformed the data to meet general premise required by the test (Zar 2010). Instead of using box plots to graphically represent mean data distribution we decided on using density dot plots with the raw data. We believed this type of data illustration could be more informative and thus lead to a better understanding of reasonable biological processes which could be relevant in the studied area (Magnusson and Mourão 2005).

We carried out all analyses in the R v. 2.12.2 environment (R Development Core Team 2011). We used functions of its basic interface and package Vegan (Oksanen 2011).

\section{RESULTS}

\section{SPECIES COMPOSITION}

We found a total of 34 ferns and one lycophyte species representing 25 genera and 14 families within the study area. Pteridaceae was the richest family and the most represented genera were Adiantum (Pteridaceae) and Asplenium (Aspleniaceae) (Table I). The majority $(66 \%)$ of the species sampled were classified as terrestrial, 
varying among tree ferns (two species of Cyatheaceae), climbers on the lower segments of tree trunks (Lygodium volubile) or other typically ground-rooting species (Table I). Eleven percent of species were epiphytic (hemiepiphytic or facultative epiphyte), and 23\% were epilithic. Of 1132 individuals recorded, $77 \%$ belonged to species classified as terrestrial, $21 \%$ of individuals belonged to epilithic species and just $2 \%$ belonged to epiphytic species.

TABLE I

Composition, habit number of individuals of Ferns and Lycophytes species found in the two studied sites (A and B) of Marambaia paleoisland, State of Rio de Janeiro, Brazil. Habit categories: terrestrial - T; epilithic - E; hemiepiphytic HE; climbing - C; facultative epiphyte - FE.

\begin{tabular}{|c|c|c|c|c|}
\hline Families/Species & Habit & Site A & Site B & Voucher \\
\hline \multicolumn{5}{|l|}{ LYCOPHYTES SELAGINELLACEAE } \\
\hline Selaginella muscosa Spring & $\mathrm{T}$ & 7 & & Damasceno \& Souza Jr. s.n. (RBR 32.652) \\
\hline \multicolumn{5}{|l|}{ FERNS ANEMIACEAE } \\
\hline Anemia mandioccana Raddi & $\mathrm{E}$ & 54 & 49 & Nettesheim \& Damasceno s.n. (RBR 34.939) \\
\hline Anemia phyllitidis Sw. & $\mathrm{T}$ & 34 & 3 & Nettesheim \& Damasceno s.n. (RBR 34.949) \\
\hline \multicolumn{5}{|l|}{ ASPLENIACEAE } \\
\hline Asplenium regulare $\mathrm{Sw}$. & $\mathrm{T}$ & & 3 & Nettesheim et al. s.n. (RBR 34.953) \\
\hline Asplenium serratum L. & $\mathrm{FE}$ & 2 & 1 & Nettesheim \& Damasceno s.n. (RBR 34.936) \\
\hline $\begin{array}{l}\text { Hymenasplenium triquetrum (N. Murak. \& } \\
\text { R. C. Moran) L. Regalado \& Prada }\end{array}$ & $\mathrm{E}$ & 3 & 1 & Nettesheim et al. s.n. (RBR 34.959) \\
\hline \multicolumn{5}{|l|}{ BLECHNACEAE } \\
\hline Blechnum brasiliense Desv. & $\mathrm{T}$ & & 1 & Nettesheim \& Damasceno s.n. (RBR 34.946) \\
\hline \multicolumn{5}{|l|}{ CYATHEACEAE } \\
\hline Cyathea corcovadensis (Raddi) Domin & $\mathrm{T}$ & 14 & & Damasceno \& Souza Jr. s.n. (RBR 32.651) \\
\hline Cyathea leucofolis Domin & $\mathrm{T}$ & 4 & & Damasceno \& Souza Jr. s.n. (RBR 32.659) \\
\hline \multicolumn{5}{|l|}{ DRYOPTERIDACEAE } \\
\hline Ctenitis deflexa (Kaulf.) Copel. & $\mathrm{T}$ & & 54 & Nettesheim \& Amorim s.n. (RBR 34.963) \\
\hline Ctenitis fenestralis (C.Chr.) Copel. & $\mathrm{T}$ & 52 & & Damasceno \& Souza Jr. s.n. (RBR 32.639) \\
\hline $\begin{array}{l}\text { Mickelia scandens (Raddi) R. C. Moran, } \\
\text { Labiak \& Sundue }\end{array}$ & $\mathrm{HE}$ & 2 & 13 & Nettesheim \& Damasceno s.n. (RBR 34.947) \\
\hline Olfersia cervina (L.) Kunze & $\mathrm{T}$ & & 2 & Nettesheim \& Damasceno s.n. (RBR 34.945) \\
\hline \multicolumn{5}{|l|}{ HYMENOPHYLLACEAE } \\
\hline $\begin{array}{l}\text { Abrodicityum rigidum (Sw.) Ebihara \& } \\
\text { Dubuisson }\end{array}$ & $\mathrm{T}$ & 10 & & Damasceno \& Souza Jr. s.n. (RBR 32.655) \\
\hline $\begin{array}{l}\text { Polyphlebium pyxidiferum (L.) Ebihara \& } \\
\text { Dubuisson }\end{array}$ & $\mathrm{E}$ & 1 & & Damasceno \& Souza Jr. s.n. (RBR 32.653) \\
\hline Vandenboschia radicans (Sw.) Copel. & $\mathrm{E}$ & & 4 & Nettesheim \& Damasceno s.n. (RBR 34.967) \\
\hline $\begin{array}{l}\text { Vandenboschia rupestris (Raddi) Ebihara \& } \\
\text { K. Iwats. }\end{array}$ & $\mathrm{E}$ & & 1 & Nettesheim \& Damasceno s.n. (RBR 34.937) \\
\hline \multicolumn{5}{|l|}{ LINDSAEACEAE } \\
\hline Lindsaea lancea (L.) Bedd. & $\mathrm{T}$ & 15 & 2 & Nettesheim \& Damasceno s.n. (RBR34.942) \\
\hline \multicolumn{5}{|l|}{ LOMARIOPSIDACEAE } \\
\hline Lomariopsis marginata (Schrad.) Kuhn & $\mathrm{HE}$ & 4 & 6 & Nettesheim et al. s.n. (RBR 34.960) \\
\hline \multicolumn{5}{|l|}{ LYGODIACEAE } \\
\hline Lygodium volubile $\mathrm{Sw}$. & $\mathrm{C}$ & 13 & 31 & Nettesheim \& Fonseca s.n. (RBR 34.954) \\
\hline \multicolumn{5}{|l|}{ POLYPODIACEAE } \\
\hline Campyloneurum lapathifolium (Poir.) Ching & $\mathrm{E}$ & & 56 & Nettesheim et al. s.n. (RBR 34.961) \\
\hline
\end{tabular}


TABLE I (continuation)

\begin{tabular}{|c|c|c|c|c|}
\hline Families/Species & Habit & Aspect A & Aspect B & Voucher \\
\hline \multicolumn{5}{|l|}{ POLYPODIACEAE } \\
\hline Microgramma tecta (Kaulf.) Alston & $\mathrm{E}$ & & 1 & Nettesheim \& Damasceno s.n. (RBR 34.948) \\
\hline $\begin{array}{l}\text { Pecluma plumula (Humb. \& Bonpl. ex } \\
\text { Willd.) M.G. Price }\end{array}$ & $\mathrm{E}$ & 2 & & Damasceno s.n. (RBR 29.319) \\
\hline $\begin{array}{l}\text { Pleopeltis minima (Bory) J. Prado \& R.Y. } \\
\text { Hirai }\end{array}$ & $\mathrm{FE}$ & & 2 & Nettesheim \& Damasceno s.n. (RBR 29.318) \\
\hline \multicolumn{5}{|l|}{ PTERIDACEAE } \\
\hline Adiantopsis radiata $(\mathrm{L}$.) Fée & $\mathrm{T}$ & 35 & & Damasceno \& Nettesheim s.n. (RBR 29.317) \\
\hline Adiantum abscissum Schrad. & $\mathrm{T}$ & 47 & 216 & Nettesheim \& Damasceno s.n. (RBR 34.940) \\
\hline Adiantum latifolium Lam. & $\mathrm{T}$ & 44 & 1 & Damasceno \& Souza Jr. s.n. (RBR 32.664) \\
\hline Adiantum pulverulentum $\mathrm{L}$. & $\mathrm{T}$ & & 40 & Nettesheim \& Amorim s.n. (RBR 34.964) \\
\hline Pteris brasiliensis Raddi & $\mathrm{T}$ & & 16 & Nettesheim \& Amorim s.n. (RBR 34.965) \\
\hline Pteris denticulata Sw. var. denticulata & $\mathrm{T}$ & 12 & 1 & Nettesheim \& Damasceno s.n. (RBR 34.938) \\
\hline \multicolumn{5}{|l|}{ TECTARIACEAE } \\
\hline Tectaria incisa Cav. & $\mathrm{T}$ & 1 & & Damasceno \& Souza Jr. s.n. (RBR 32.656) \\
\hline Tectaria pilosa (Fée) R. C. Moran & $\mathrm{T}$ & & 2 & Nettesheim \& Amorim s.n. (RBR 34.951) \\
\hline \multicolumn{5}{|l|}{ THELYPTERIDACEAE } \\
\hline Macrothelypteris torresiana (Gaudich.) Ching & $\mathrm{T}$ & 1 & & Damasceno \& Souza Jr. s.n. (RBR 32.654) \\
\hline Thelypteris polypodioides (Raddi) C. F. Reed & $\mathrm{T}$ & 72 & 78 & Nettesheim \& Damasceno s.n. (RBR 34.943) \\
\hline Thelypteris vivipara (Raddi) Ching & $\mathrm{T}$ & 77 & 43 & Nettesheim \& Fonseca s.n. (RBR 34.956) \\
\hline
\end{tabular}

FERNS AND LYCOPHYTES COMMUNITIES IN SLOPES

\section{DISTINCTIVELY ORIENTATED}

Site A had 506 individuals divided into 23 species in 19 genera and 13 families (Table I), with a total estimated plant cover of $5,950.6 \mathrm{~m}^{2} \mathrm{ha}^{-1}$. In site $\mathrm{B}$ we found 627 individuals representing 25 species, 18 genera and 12 families (Table I), with an estimated plant cover of $2,623.8 \mathrm{~m}^{2} \mathrm{ha}^{-1}$. Similarity analysis with qualitative data registered a resemblance of $57.1 \%$ between sites. This value dropped to $24.8 \%$ when quantitative data was used to calculate similarity. Multivariate analyses are in agreement with these similarity results. Final NMDS configuration stress is 0.16 and the proportion of variance $\left(\mathrm{r}^{2}\right)$ captured by analysis is 0.57 . The bivariate Gauss ellipses drawn on the ordination graph for each site (Fig. 1) indicate there is differentiation of ferns and lycophytes communities between the two contiguous sites. This pattern is supported by Student's t-test results for axis $1(\mathrm{t}=-3.9$; $\mathrm{df}=48.27 ; \mathrm{p} \leq 0,001)$, but not for axis $2(t=0.6 ; d f=57.9 ; p=0.553)$. So we can reject the null hypothesis of no floristic variation between the differently guided slopes of a Marambaia paleoisland. According to the Pearson's coefficient species vectors, Adiantopsis radiata, Ctenitis fenestralis and Anemia phyllitidis are associated with site A. Ctenitis deflexa, Thelypteris polypodioides, Adiantum pulverulentum and Adiantum abscissum are related to site B (Fig. 2).

The differentiation pattern evidenced by NMDS and Student's $\mathrm{t}$-test on the first axis ordination values was not detected by our parametric analysis. According to Student's t-test, sites A and B have no differences in total richness $(\mathrm{t}=-1.16$; $\mathrm{df}=55.2$; $\mathrm{p}=0.249 ;$ Fig. $3 \mathrm{a})$, plant cover $(\mathrm{t}=1.88 ; \mathrm{df}=47.23$; $\mathrm{p}=0.066$; Fig. $3 \mathrm{~b})$ or abundance $(\mathrm{t}=-1.09$; $\mathrm{df}=57.7 ; \mathrm{p}=0.279 ;$ Fig. $3 \mathrm{c})$. Therefore, we cannot reject the null hypothesis of no differences between the sites richness, abundance and plant cover.

\section{DISCUSSION}

Preliminary qualitative similarity analysis indicates a relatively low number of shared species between 


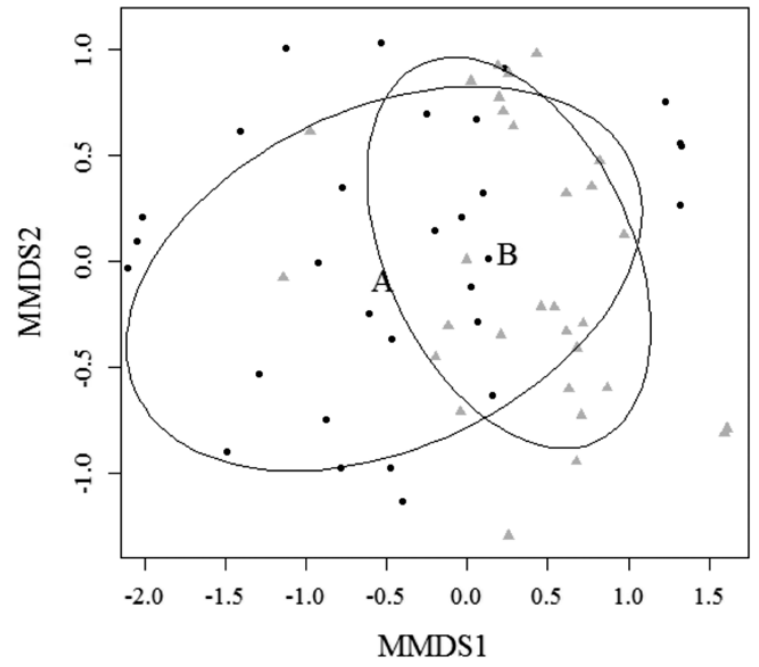

Fig. 1 - Final ordination of the 60 plots. Black dots represent the plots at site A and gray triangles are plots at site B. Gauss ellipses outline each site's data variation, as shown by letters A and B.

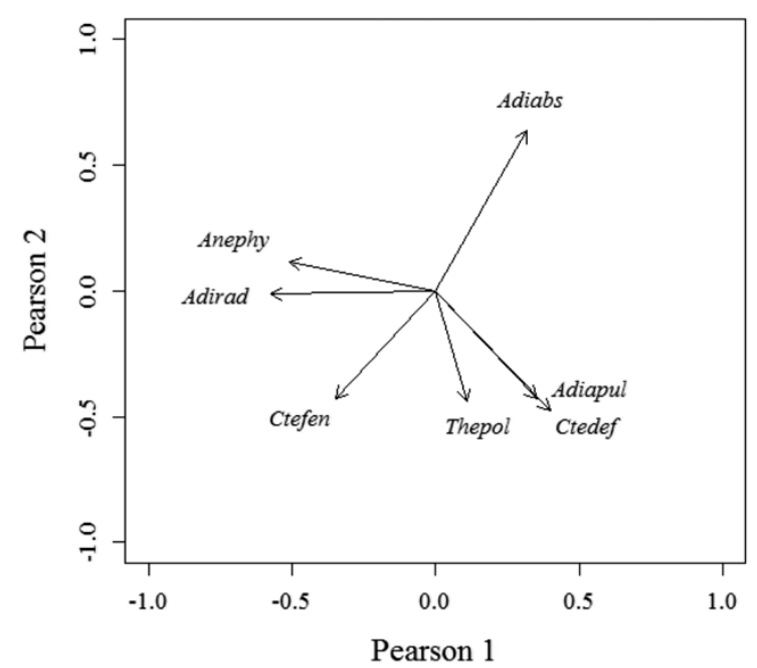

Fig. 2 - Vectors representing Species Pearson coefficients with the MMDS axis. Only vectors with correlation $(\geq 0,4)$ are shown on the graph. Adiabs - Adiantum abscissum; Adipul - Adiantum pulverulentum; Adirad - Adiantum raddianum; Anephy-Anemia phyllitidis; Ctedef - Ctenitis deflexa; Ctefen - Ctenitis fenestralis; Thepol - Thelypteris polypodioides.

sites. This is especially true when considering that both areas are adjacent and most likely under the influence of the same species pool (Jones et al. 2006). The decrease of this similarity with quantitative data was considerable, supporting that quantitative data is a more faithful illustration of the plant community
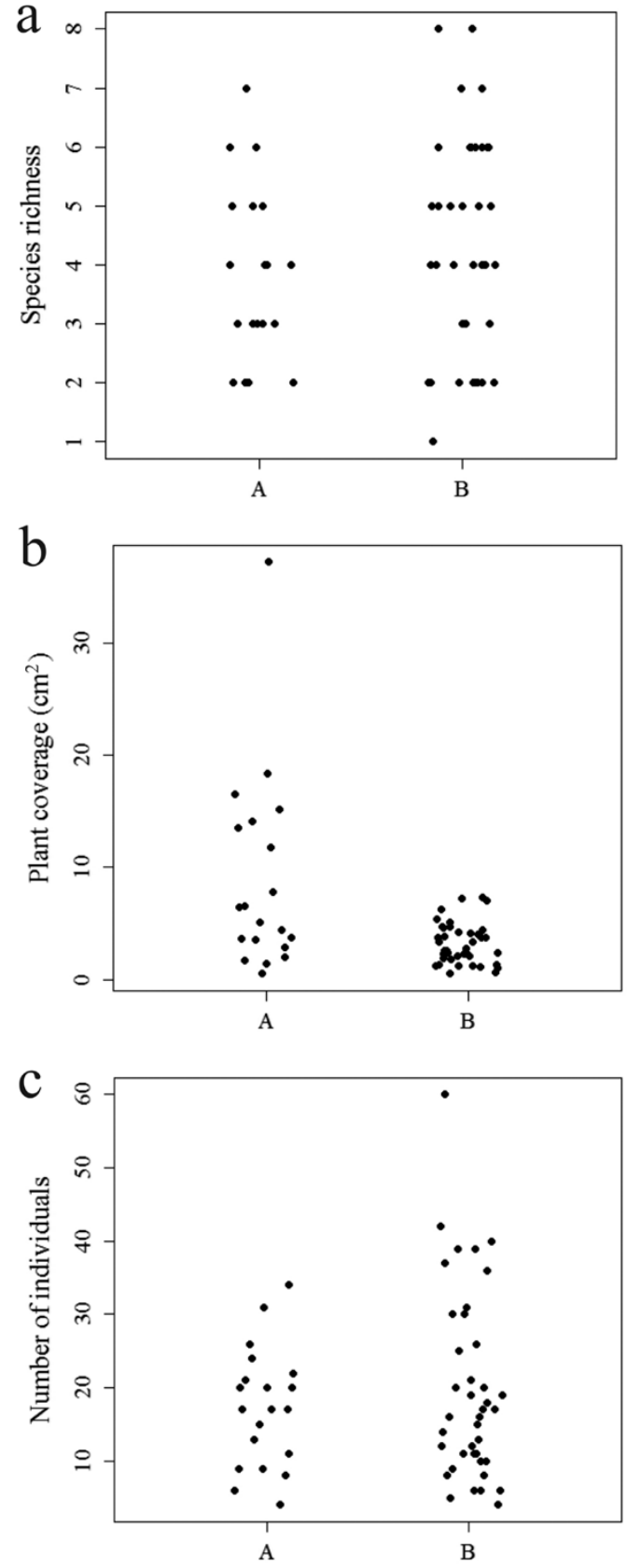

Fig. 3 - Ferns and Lycophytes species (a) richness, (b) plant cover and (c) abundance at sites A and B. Points represent the raw values recorded at the plots on each site.

than simply species presence/absence data (McCune and Grace 2002, Gotelli and Ellison 2004). A study in four Amazonian forest sites by Tuomisto and Poulsen (2000) found similarity values close to the ones in this study, between $47 \%$ and $58 \%$, but the 
areas were up to $600 \mathrm{~km}$ apart. Such a distinction could be associated to differences in topography of the Atlantic and Amazon forests (Vormisto et al. 2004, Jones et al. 2006, 2008). The Atlantic forest is known for its wide range distribution along the Brazilian coast, presenting a quite variable topography and thus a broad array of environmental factors (Oliveira-Filho and Fontes 2000, Tonhasca Jr. 2005, Nettesheim et al. 2010). Despite its variable terrain and habitat heterogeneity, the Amazon forest can be considered to have a rather plain topography and mild collection of environmental factors when compared to its eastern close relative, the Atlantic forest (Rizzini 1997, Tuomisto et al. 2003a, b, c). Perhaps, the low ferns and lycophytes similarity values between the Marambaia paleoisland slopes is a consequence of the topographic heterogeneity of this forest (Tuomisto et al. 2002, Karst et al. 2005, Jones et al. 2006, 2008, Nettesheim et al. 2010).

Ferns and lycophytes floristic variation between the slopes was confirmed when taking into account species occurrence and plant cover data simultaneously with multivariate analysis. Plots ordination made evident the differentiation pattern between northwestern and southwestern slopes (Fig. 1). Recent findings point out the important role of the environment component in structuring plant communities and how it can vary according to the scale evaluated, underlying geology and topography. The environmental determinism over plants distribution has thus received increasing attention and is considered essential towards the evaluation and comprehension of species coexistence models (Svenning et al. 2004, 2006, Karst et al. 2005, Jones et al. 2008, Zuquim et al. 2009, Li et al. 2011). Therefore, it is reasonable to think that the ferns and lycophytes community differentiation pattern that we found may have emerged from environment variation related to the slope topographic orientation. This inference should be further tested by replicating this study at other topographically variable landscapes across a broader geographic range within the Atlantic
Forest. Such effort may allow for a greater capacity of more fully exploring the factors controlling ferns and lycophytes communities structuring in tropical forests over terrain with a variable topography.

Some studies argue that topographic patterns are site-specific and slope effects seem to be a bad surrogate for the prediction of community structure because it is probably a synergistic response of the community to variable factors (Vormisto et al. 2004, Zuquim et al. 2009). We agree with this viewpoint, but slope topographic orientation may influence factors that are knowingly more important than others to a specific biological group. For instance, both moisture and light are limiting factors for plants, particularly affecting ferns (Page 2002, Kessler et al. 2007). Having that in mind, topographic orientation can facilitate moisture conservation, once the exposure period and quality of the solar rays vary according to the incidence angle of sunlight. Slopes turned to northern directions have greater exposure to the incidence of sunlight along the year than those turned to southern directions (Lima 1986, Oliveira et al. 1992, Marques et al. 2005). Not only that, but along the Atlantic forest, slopes facing the sea are generally more humid, once they represent the first conspicuous barrier to rain and sea air coming from the ocean (Oliveira-Filho and Fontes 2000, Oliveira-Filho et al. 2005, Paciencia and Prado 2005, Nettesheim et al. 2010). Even if slope orientation promotes a possible synergistic response of the ferns and lycophytes communities, mainly to moisture and light, it is reasonable to assume that the topographic heterogeneity of the Atlantic forest enhances its relevance to predict the floristic variation of these groups in this forest.

Under this framework, we are led to believe that the processes responsible for the community differentiation pattern detected are mostly related to moisture and light incidence differences caused by the variation of slope geographic orientation. Even though slope orientation may determine ferns and lycophytes communities floristic variation, these environment changes do not seem to establish 
detectable differences between the slopes community richness, abundance or plant cover. Such a fact may be indicative that the ferns and lycophytes communities on evaluated slopes have possibly come into a dynamic balance. Each area presents a species composition of its own (Table I), most likely adapted to the current environmental conditions of the slopes within which they occur (Kessler et al. 2007, Kessler and Lehnert 2009, Kluge and Kessler 2011). If so, the acknowledgment that these species are well established and explore succesfully the available resources of the slopes, could help to explain why we could not find differences in the tested community atributes. Supporting this interpretation, we were able to identify distinct species closely related to each of the studied sites and thus responsible for the differentiation pattern detected in NMDS (Fig. 1). If floristic variation is indeed related to moisture and light incidence differences caused by slope orientation, it is reasonable to hypothesize about the potential ecological preferences of species most strongly linked to each of the areas. Therefore, association of Adiantopsis radiata, Ctenitis fenestralis and Anemia phyllitidis with site A, allegedly arid relative to site $\mathrm{B}$, reasonably suggests these species are more adapted to drier places with more sunlight incidence. Meanwhile, association of Ctenitis deflexa, Thelypteris polypodioides, Adiantum pulverulentum and Adiantum abscissum with site $\mathrm{B}$, supposedly more humid and with less sunlight incidence, may be indicative of their preferences for more humid and shaded places. These species preferences for such environmental characteristics may explain why they are important in structuring ferns and lycophytes communities on slopes with distinct geographic orientation.

The lack of plant cover difference between ferns and lycophytes communities in the slopes was not expected. Perhaps species which occur on northwestern slopes are adapted to more arid locations, given the allegedly greater light incidence at slopes guided to northern directions (Oliveira et al. 1992, Marques et al. 2005). Though this remains to be tested, such adaption and the energy income at these areas can possibly allow plants to reach similar plant cover as in more attractive humid areas.

An interesting fact regarding plant cover at the sites was the detection of an outlier plot at this variable's raw data density dot graph (Fig. 3b). This plot has considerably bigger plant cover value relative to all the other study plots. The source of this variation may be attributed to the random joint occurrence of Cyathea leucofolis, the biggest sampled fern individual of the study (a tree fern) and a large number of Ctenitis fenestralis, the species with biggest total plant cover in the study. C. fenestralis had an apparent patchy distribution, seeing that it was registered just in 6 plots, three of which gathered almost all of its sampled individuals. That sort of distribution was not restricted to this species and may be caused by dispersal limitation. This common process appears to also structure plant communities, contributing to the increase of floristic variation as scale decreases (Wolf et al. 2001, Karst et al. 2005, Svenning et al. 2006, Jones et al. 2006, 2008). Recent studies point out dispersal limitation and environmental determinism (sometimes their interaction) as essential in evaluating competing models of plant species coexistence at tropical forests, from fine to broad scales (Svenning et al. 2004, 2006, Jones et al. 2006, 2008, 2011).

Our study provides evidence that there is significant floristic variation of the ferns and lycophytes communities between slopes with different topographic orientation of the Marambaia paleoisland. The slopes do not have different community richness, abundance or plant cover, but present considerable species turnover among them. Apparently such a variation is caused both by environmental and biotic factors, being in general agreement with latest findings in explaining plant communities structuring processes. We hypothesize that the most relevant factors driving differentiation between slopes are probably moisture and light incidence (environmental data) 
due to area topography and to the biology of this biological group, but this remains to be tested. It seems that dispersal limitation (spatial data) might also be of particular importance at the studied scale. Quantifying these and other environmental and spatial variables across this and greater geographic ranges would allow insights into the explanatory power of a set of possible factors driving ferns and lycophytes floristic variation at the Atlantic Forest. Information like this can provide better predictive models of ferns and lycophytes species distribution in tropical forests. Therefore, it is important that future studies look for confirmation if indeed slope topographic orientation, moisture, light incidence and dispersal limitation are as relevant as we postulate to ferns and lycophytes along the Atlantic forest.

\section{ACKNOWLEDGMENTS}

We thank the Centro de Adestramento da Ilha da Marambaia (CADIM) for supporting field work and two anonymous reviewers who provided helpful comments to improve the quality of this manuscript. This project was funded by the Conselho Nacional de Desenvolvimento Científico e Tecnológico (CNPq) in Brazil (Proc. n. 309415/2008-0) and Fundação Carlos Chagas Filho de Amparo à Pesquisa do Estado do Rio de Janeiro (FAPERJ, Proc. n. E-26/152.312/2006).

\section{RESUMO}

Uma comunidade de Samambaias e Licófitas de um ecossistema insular do Sudeste do Brasil foi investigada através da comparação da ocorrência de espécies em diferentes vertentes. Nosso objetivo foi avaliar a hipótese que vertentes com orientações geográficas diferentes determinam a diferenciação da comunidade de Samambaias e Licófitas na floresta atlântica. Nós registramos estas plantas em vertentes voltadas para o continente e para o oceano. As análises consistiram em uma avaliação preliminar da diversidade beta das samambaias, uma Análise de Escalonamento Multidimensional
Não Métrico (NMDS) e um teste $\mathrm{T}$ de Student para confirmar se a ordenação das unidades amostrais das áreas foi diferente em cada eixo. Adicionalmente, nós aplicamos o coeficiente de Pearson para relacionar espécies de samambaias ao padrão de diferenciação da comunidade e mais testes $\mathrm{T}$ de Student para avaliar se a riqueza, cobertura e abundância variavam entre os dois sítios. Foi registrado um número relativamente baixo de espécies compartilhadas entre os dois sítios, confirmando a variação florística das samambaias e licófitas. Algumas espécies foram apontadas como indicadoras da variação da comunidade, mas não foi possível detectar diferenças na riqueza, cobertura e abundância. Apesar da evidência desta variação entre as vertentes, trabalhos futuros são necessários para avaliar quais processos contribuem na determinação deste padrão.

Palavras-chave: floresta atlântica, topografia, pteridófitas, riqueza, fatores ambientais.

\section{REFERENCES}

ALMEIDA FFM AND CARNEIRO CR. 1998. Origem e evolução da Serra do Mar. Rev Bras Geocienc 282: 1-20.

BARBOSA JPM. 2007. Mudanças climáticas e distribuição espacial da precipitação na Serra do Mar - Análises a partir de séries históricas de precipitação e sistema de informação geográfica SIG. Caminhos Geogr 8: 67-81.

BARRINGTON DS. 1993. Ecological and historical factors in fern biogeography. J Biogeogr 203: 275-279.

Chazdon RL, PEARCy RW, LeE DW AND FEtcher N. 1996. Photosynthetic responses of tropical forest plants to contrasting light environments. In: MULKEY SS, CHAZDON RL AND SMITH AP (Eds), Tropical forest plant ecophysiology. New York: Chapman and Hall, p. 5-55.

Condit R, Pitman N, Leigh JR EG, Chave J, Terborgh J And FOSTER RB. 2002. Beta diversity in tropical forest trees. Sci 295: 666-669.

DALling JW, MULler-LANDAU HC, Wright SJ AND HubBell SP. 2002. Role of dispersal in the recruitment limitation of neotropical pioneer species. J Ecol 90: 714-727.

Duarte LS, Hofmann GS, SANTOS MMG, HaRTz SM AND PILLAR VD. 2010. Testing for the influence of niche and neutral factors on sapling community assembly beneath isolated woody plants in grasslands. J Veg Sci 21: 462-471.

DUIVENVOORDEN JF, SVENNING JC AND WRIGHT SJ. 2002. Beta Diversity in Tropical Forests. Sci 295: 636-637.

ENGELBRECHT BMJ, Kursar TA AND TYREE MT. 2005. Drought effects on seedling survival in a tropical moist forest. Trees 19: 312-321. 
GARbin ML, CARrijo TT, SANSEVERo JBB, SANChÉZ-TAPIA A AND SCARANO FR. 2012. Subordinate, not dominant, woody species promote the diversity of climbing plants. Perspect Plant Ecol Evol Syst 14: 257-265.

GAUCH HG. 1982. Multivariate analysis in community ecology. Cambridge: Cambridge University Press, 298 p.

Gotelli N AND ElLison AM. 2004. A primer of ecological statistics. Massachusetts: Sinauer Associates, 614 p.

HuBBELL SP. 2001. The unified neutral theory of biodiversity and biogeography. Princeton: Princeton University Press, $375 \mathrm{p}$.

Jones MM, TuOmisto H, BorCARd D, LEgEndre P, Clark DB AND OLIVAS PC. 2008. Explaining variation in tropical plant community composition: influence of environmental and spatial data quality. Oecologia 55: 593-604.

Jones MM, TuOmisto H, Clark DB AND Olivas P. 2006. Effects of mesoscale environmental heterogeneity and dispersal limitation on floristic variation in rain forest ferns. J Ecol 94: 181-195.

JONEs MM, SZYSKA B AND KessLeR M. 2011. Microhabitat partitioning promotes plant diversity in a tropical montane forest. Global Ecol Biogeogr 20: 558-569.

KARST J, GILBERT B AND LECHOWICZ MJ. 2005. Fern community assembly: the roles of chance and the environment at local and intermediate scale. Ecol 86: 2473-2486.

KeSSLER M AND LEHNERT M. 2009. Do ridge habitats contribute to pteridophyte diversity in tropical montane forests? A case study from southeastern Ecuador. J Plant Res 122: 421-428.

Kessler M, Siorak M, Wunderlich M AND Wegner C. 2007. Patterns of morphological leaf traits among pteridophytes along humidity and temperature gradients in the Bolivian Andes. Funct Plant Biol 34: 963-971.

KLuge J AND Kessler M. 2011. Phylogenetic diversity, trait diversity and niches: species assembly of ferns along a tropical elevational gradients. J Biogeogr 38: 394-405.

KÖPPEN W. 1948. Climatologia. Ed. Fundo de cultura económica. México, 478 p.

LEGENDRE P AND GALlAGHER ED. 2001. Ecologically meaningful transformations for ordination of species data. Oecologia 129: 271-280.

Li Q, YANG X, SOININEN J, CHU C, ZHANG J, YU K AND WANG G. 2011. Relative importance of spatial and environmental factors in shaping alpine meadow communities. J Plant Ecol 4: 249-258.

LIMA WP. 1986. Princípios de hidrologia florestal para o manejo de bacias hidrográficas. Piracicaba: Universidade de São Paulo, 241 p.

Machado ELM AND OliveIRA-Filho AT. 2010. Spatial patterns of tree community dynamics are detectable in a small (4 ha) and disturbed fragment of the Brazilian Atlantic forest. Acta Bot Bras 24(1): 250-261.

Magnusson WE AND MourÃo G. 2005. Estatística [Sem] Matemática - a ligação entre as questões e a análise. Londrina: Editora Planta, 136 p.
MAGURRAN AE. 2004. Measuring biological diversity. Oxford: Blackwell Science Ltd, 256 p.

MARques MCM, SwaINE MD AND LIEBSCH D. 2011. Diversity distribution and floristic differentiation of the coastal lowland vegetation: implications for the conservation of the Brazilian Atlantic Forest. Biodivers Conserv 20: 153-168.

MARQues O, TiEnNE L, CORTINES E AND VALCARCEL R. 2005. Atributos ambientais definidores de presença de fragmentos florestais de Mata Atlântica em microbacias instáveis. Revista Univ Rural - Ciências da Vida 24: 145-150.

MatTos CLV. 2005. Caracterização climática da Restinga da Marambaia. In: MENEZES LFT, PEIXOTO AL AND ARAÚJO DSD (Eds), História Natural da Marambaia. Seropédica: Editora da Universidade Rural, p. 55-66.

MCCNUNE B AND GRACE JB. 2002. Analysis of ecological communities. MjM Software Design, Gleneden Beach, Oregon, $300 \mathrm{p}$.

MENEZES LFT AND ARAÚJO DS. 2000. Variação da biomassa aérea de Allagoptera arenaria (Gomes) O. Kuntze (Arecaceae) em uma comunidade arbustiva de Palmae na restinga de Marambaia, RJ. Rev Bras Biol 60: 147-157.

Menezes LFT, PeiXoto AL AND ARAujo DS. 2005. História Natural da Marambaia. Seropédica: Editora da Universidade Rural, 288 p.

NetTesheim FC, MENEZES LFT, CARVALHo DC, Conde MMS AND ARAUJO DS. 2010. Influence of environmental variation on Atlantic Forest tree-shrub-layer phytogeography in southeast Brazil. Acta Bot Bras 24: 369-377.

OKSANEN J. 2011. Vegan: ecological diversity. http://CRAN.Rproject.org/package=vegan. Acessado em fevereiro de 2011.

Oliveira JB, JACOMINE PKT AND CAMARgo MN. 1992. Classes gerais de solos do Brasil: guia auxiliar para seu reconhecimento. Jaboticabal: FUNEP, 201 p.

OLIVEIRA-FILHO AT AND FONTES MAL. 2000. Patterns of floristic diferentiation among Atlantic Forest in southeastern Brazil and the influence of climate. Biotropica 32: 793-810.

Oliveira-Filho AT, Neto ET, CARVALHo WAC, WERnECK M, Brina AE, VidAl CV, REZENDE SC AND PEREIRA JAA. 2005. Análise florística do compartimento arbóreo de áreas de floresta atlântica sensu lato na região das bacias do leste (BA, MG, ES e RJ). Rodriguésia 56: 185-235.

PACIÊNCIA MLB AND PRADO J. 2005. Distribuição espacial da assembléia de pteridófitas em uma paisagem fragmentada de Mata Atlântica no sul da Bahia, Brasil. Hoehnea 32: 103-117.

PAGE C. 2002. Ecological strategies in fern evolution: a neopteridological overview. Review Palaeobot Palynol 119: 1-33.

Phillips OL, NúÑEZ VARgas P, LoRenzo Monteagudo A, Peña Cruz A, Chuspe Zans ME, Galiano Sánchez W, Yli-Halla M and Rose S. 2003. Habitat association among Amazonian tree species: a landscape-scale approach. J Ecol 91: 757-775.

PICHI SERMOLLI REG. 1996. Authors of scientific names in pteridophyta. Kew: Royal Botanic Gardens, 78 p. 
Pitman NCA, Terborgh JW, Miles R, Silman PNV, NeILl DA AND CERÓN CE. 2001. Dominance and distribution of tree species in upper Amazonian terra firme forests. Ecol 83: 2101-2117.

PotTs MD, Ashton PS, KAUfMAn LS AND PlotKIn JB. 2002. Habitat patterns in tropical rain forests: a comparison of 105 plots in northwest Borneo. Ecol 83: 2782-2797.

R Development Core Team. 2011. R: A language and environment for statistical computing, R Foundation for Statistical Computing, Vienna, Austria. http:/www.Rproject.org.

RICKLEFS RE AND RENNER SS. 2012. Global Correlations in Tropical Tree Species Richness and Abundance Reject Neutrality. Science 335: 464-467.

RIZZINI CT. 1997. Tratado de fitogeografia do Brasil: aspectos sociológicos, ecológicos e florísticos. Rio de Janeiro: Âmbito Cultural Edições, 747 p.

RuOKOLAinen K, LinNA A And TuOMisto H. 1997. Use of Melastomataceae and pteridophytes for revealing phytogeographical patterns in Amazonian rain forests. J Trop Ecol 13: 243-256.

SMith AR, Pryer KM, SchuetTPElz E, KorAll P, SchNeIdER H AND WOLF PG. 2006. A classification for extant ferns. Taxon 55: 705-731.

SONOIKE K. 1996. Photoinhibition of photosystem I: its physiological significance in the chilling sensitivity of pants. Plant Cell Physiol 37: 239-247.

Souza CRG, Suguio K, Oliveira AMS and Oliveira PE. 2005. Quaternário do Brasil. Ribeirão Preto: Editora Holos, $382 \mathrm{p}$.

SVENNING JC. 1999. Microhabitat specialization in a species rich palm community in Amazonian Equador. J Ecol 87: 55-65.

SVENNING JC, ENGELBRECHT BMJ, KINNER DA, KuRSAR TA, STALLARD RF AND WRIGHT SJ. 2006. The relative roles of environment, history and local dispersal in controlling the distributions of common tree and shrub species in a tropical forest landscape, Panama. J Trop Ecol 22: 575-586.

SvenNing JC, FitzPatrick MC, NORMAND S, GAHAM CH, PEARMAN PB, IVERSON LR AND SKOV F. 2010. Geography, topography, and history affect realized-to-potential tree species richness patterns in Europe. Ecography 33: 1070-1080

SVENNING JC, KINNER DA, STALLARD RF, ENGELBRECHT BMJ AND WRIGHT SJ. 2004. Ecological determinism in plant community structure across a tropical forest landscape. Ecol 85: 2526-2538.

Ter Steege H, Pitman N, Sabatier D, Castellanos H, Van Der Hout P AND DALY DC. 2003. A spatial model of tree alfa diversity and tree density for the Amazon. Biodivers Conserv 12: 2255-2277.
TONHASCA JR A. 2005. Ecologia e história natural da Mata Atlântica. Rio de Janeiro: Editora Interciência, 197 p.

TRYON RM AND TRYON AF. 1982. Ferns and allied plants, with special reference to Tropical America. New York: Springer Verlag, $857 \mathrm{p}$.

TuOMisto H And Poulsen AD. 2000. Pteridophyte diversity and species composition in four Amazonian rain forests J Veg Sci 11: 383-396.

TuOmisto H, Poulsen AD, RuOKOlainen K, Moran RC, QUINTANA C AND CAÑAS G. 2003a. Linking floristic patterns with soil heterogeneity and satellite imagery in Ecuadorian Amazonia. Ecol Appl 13: 352-371.

TUOMisto H, RUOKOLAINEN K, AgUILAR M AND SARMIENTO A. 2003b. Floristic patterns along a 43-km long transect in an Amazonian rain forest. J Ecol 91: 743-756.

Tuomisto H, Ruokolainen K, Poulsen AD, Moran RC, Quintana C, CAÑAS G AND CELI J. 2002. Distribution and diversity of Pteridophytes and Melastomataceae along edaphic gradients in Yasuní National Park, Ecuadorian Amazonia. Biotropica 344: 516-533.

TuOmisto H, RuOKOLAINEN K AND Yli-Halla M. 2003c. Dispersal, environmental, and floristic variation of Western Amazonian forests. Sci 299: 241-244.

VELOSO HP, RANGEL FILHO ALR AND LIMA JCA. 1991. Classificação da vegetação Brasileira adaptada a um sistema universal. Rio de Janeiro: Instituto Brasileiro de Geografia e Estatística, 123 p.

Vormisto J, TuOmisto H And OKsanen J. 2004. Palm distribution patterns in Amazonian rainforests: what is the role of topographic variation? J Veg Sci 15: 485-494.

Wolf PG, SCHNEIDER H AND RANKER T. 2001. Geographic distributions of homosporous ferns: does dispersal obscure evidence of vicariance? J Biogeog 28: 263-270.

WYATT JL AND SILMAN MR. 2004. Distance-dependence in two Amazonian palms: effects of spatial and temporal variation in seed predator communities. Oecologia 140: 26-35.

WYLIE RB. 1948. The dominant role of the epidermis in leaves of Adiantum. Am J Bot 35: 465-473.

ZAR JH. 2010. Biostatistical Analysis. New Jersey: Pearson Prentice Hall, 944 p.

Zuquim G, Costa FrC, Prado J And Neto RB. 2009. Distribution of pteridophyte communities along environmental gradients in Central Amazonia, Brazil. Biodivers Conserv 18: 151-166. 